\title{
Tools for innovation strategies
}

\author{
D.S. Seleznev, A.Kh. Ozdoeva \\ skyforward11@gmail.com |4305@bk.ru \\ National Research University of Oil and Gas named after I.M. Gubkin, Moscow, Russian Federation
}

\begin{abstract}
The current article is devoted to search tools for determining the optimal solution and forming the optimal company strategy for small innovative companies in the business innovation environment of the oil and gas complex. The main area of research in the article is the reasons for the difficulties of innovative Russian entrepreneurship and its entry into the domestic market and work in this market. We also consider tools such as SWIFT-analysis of assessment and forecasting of the company's performance, the portfolio model of BCG (Boston consulting group), a multi-factor matrix for selecting strategies for the most effective planning of the company's activities, as an improved version of the Arthur D. Little model. At the same time, the study revealed that a wider range of project and strategic opportunities for planning and managing a company is formed by the production and economic matrix using SWOT analysis. Thus, based on this study, the following recommendations were formulated for beginning entrepreneurs and developers in the field of innovation: take into account and apply the strategy for small innovative enterprises according to the SWOT analysis for monitoring and forecasting upcoming events (production or economic); use marketing research tools, as well as forms for planning a product plan for the life of the company; take into account that the forecast should be based on strategic analysis, using the optimal method for specific goals, and be the starting point for developing new models and business development plans.
\end{abstract}

Keywords: business strategies, cascading strategy, SWOT analysis, product plan

\section{Introduction}

The modern way of innovative development of any country can be implemented through integration with the world system. However, business models often focus exclusively on project activities and do not take into account the current management and development needs of a company, region, or country. It remains obvious that the socio-economic development of the state depends on innovations of strategic importance, including in the oil and gas industry. The synthesis of technological and economic methods can lead to GDP growth. According to statistics, the current market volume of high-tech products is 2 trillion 300 billion US dollars. According to statistics, the US accounts for $39 \%$ of this production, Japan-30\%, Germany-16\%. Russia's share is only $0.3 \%$ [1]. The national security of a country may depend on the level and volume of impact of high-tech products on the economy, its position on the world market, as well as on its activity in the economy. Thus, when forming a business strategy and determining innovative development, it is necessary to proceed from the needs of the external environment and internal potential [8]. This study defines the limits of opportunities and analyzes the resources of both companies and the state in determining innovative development using business strategies.

\section{Comparisons}

For the second half of 2018 and the first quarter of 2019 US government spent 39.24 billion dollars. to the scientific sector of the economy for development and research. The USA has increased the budgetary allocations for science since 2009 by $29 \%$. Similar expenses of Russia in 2018 amounted to 431,073.2 million rubles. (about 6.79 billion dollars). Russia has increased its budgetary allocations for science since 2009 by about $50 \%$. Thus, in relative terms, the budget expenditures of Russia for innovation are higher, but in fact in absolute terms the difference is quite noticeable (more than 5 times).

The key drawback of Russia's scientific and innovation policy is the lack of consistency in the formalization and implementation of scientific and innovative priorities. There is a gap between the development and creation of technologies, the implementation of R\&D and the release of technologies into mass production. Partly, the lag in this area is a consequence of the established administrative command system of the USSR, which does not allow fully developing many promising areas of $R \& D$, as well as the result of uncontrolled transformations of the 1990s [2].

During periods of paradigm shift, including in scientific and innovative approaches, namely, the transition from the paradigm of "catching up with foreign innovations" to the paradigm of catching up while creating something fundamentally new, and not just copying existing analogues, there are opportunities to catch up with outrun the leaders. Changing approaches makes it possible to open new paths of development, gain an advantage, and become better in their direction, while others are just learning. However, it is worth noting that one cannot just take and change landmarks, conditions must be created.

Within several years since the creation of the first nanocenter, 11 centers and 275 start-ups created by them appeared [3]. In the Sverdlovsk Region, 27 fundamentally new scientific and technical products were created: anti-corrosion materials and coatings: nanocrystalline magnetic alloys, heavy-duty parts based on hard alloys, and optoelectronic devices. In the field of computer technology, Russia has overcome a huge and difficult path, getting new modern market products based on the fundamental scientific, technical and educational backlog, formed back in the USSR and attracting international practice [4].

Thus, adaptation of Russian legislation to international standards, adopted best practices in this area, closer interaction with the global economic system, have a positive effect on the business environment of Russia, creating market growth, including fair competition, as well as a more attractive investment climate for high technology long-term forecasts [9]. 


\section{Business strategies and tools}

Working towards each other is the most reliable and shortest path to understanding and trust in public-private partnerships. Solving the problems of introducing and commercializing innovative technologies, a clear understanding and adoption of measures is necessary both from the state and from the business side. The main part of the mutual cooperation procedure begins on the part of the innovative enterprise, namely, understanding the basic elements of the company's work and business development strategy.

At present, there are 4 fundamental business strategies $[5,6]$ :

- a strategy of concentrated growth - a strategy to strengthen market positions, a market development strategy, a product development strategy;

- reduction strategy - elimination strategy, "harvest" strategy, reduction strategy, cost reduction strategy;

- diversification growth strategy - centered diversification strategy, horizontal diversification strategy;

- integrated Growth Strategy - a strategy of reverse vertical integration, a strategy of forward-going vertical integration.

Each of these strategies has its advantages and disadvantages, its capabilities and threats. A fairly clear assessment can be obtained using such tools as SWOT analysis, the portfolio model of BCG (Boston consulting group), a multi-factor matrix for selecting strategies for the most effective planning of the company's activities, as an improved version of the Arthur D. Little model (Table 1) however, the expert assessment procedure based on SWOT analysis in the course of the study has shown great informativeness and transparency for developing strategies together with representatives of large businesses, in particular innovation areas. The model included: formation of expert groups by area, analysis and evaluation of company reports by experts, including business models in the oil and gas sector. (annual reports of LUKOIL-Western Siberia, Gazprom, Novatek, Rosneft, Exxon Mobile, etc. [7]) For example, the advantage of a concentrated growth strategy is that it allows small businesses with a new product to enter the market and have a large demand, while there is a risk that larger companies that have a budget can make a similar product a year later and having a customer base successfully sell it, forcing a new manufacturer out of the market. On the other hand, the diversification strategy makes it possible to manufacture several others on the basis of one product and make the company less dependent on one product, ensure financial stability, but there is a risk of a lack of managerial personnel. The integration growth strategy allows you to attract entire teams with an administrative apparatus, which greatly simplifies and accelerates the growth rate of the production base and expands the influence on the market of an innovative company, but may entail a decrease in the competencies of the general administrative managerial staff and a deterioration in marketing awareness, which in turn can be decided individual events (additional financing). In addition, you can use the strategies already discussed earlier in a cascading way of switching from one to another. The cost reduction strategy can be attributed, in this case, as an auxiliary one, it allows at each stage to optimize the company's activities and save it from unnecessary costs, but it is not recommended to make it basic.

Table 1. SWOT analysis of business strategies

\begin{tabular}{|c|c|c|}
\hline $\begin{array}{l}\text { SWOT } \\
\text { Concentrated growth strategy }\end{array}$ & $\begin{array}{l}\text { Opportunities: } \\
\text { 1. high demand for the service } \\
\text { 2. The presence of workers, craftsmen } \\
\text { (professionals in their field) } \\
\text { 3. Availability of premises } \\
\text { 4. Availability of equipment and materials } \\
\text { 5. The possibility of raising capital } \\
\text { 6. Underemployment of the market, there } \\
\text { are free places } \\
\text { 7. Diversification of services } \\
\text { 8. The presence of a customer base for staff }\end{array}$ & $\begin{array}{l}\text { Threats: } \\
\text { 1. Competition } \\
\text { 2. High dependence of the profitability of the } \\
\text { production activity of the enterprise on changes } \\
\text { in prices for energy carriers and used raw } \\
\text { materials; }\end{array}$ \\
\hline $\begin{array}{l}\text { Strengths: } \\
\text { 1. Acceptable pricing policy } \\
\text { 2. Availability of professional staff } \\
\text { 3. Performance of quality services } \\
\text { 4. Maintaining the economic balance } \\
\text { of the company thanks to several } \\
\text { products }\end{array}$ & $\begin{array}{l}\text { Development of competitive advantages } \\
\text { (maximize opportunities) } \\
\text { 1. Holding stocks on a new product along } \\
\text { with the old } \\
\text { 2. Follow the market trend } \\
\text { 3. Make a convenient work schedule } \\
\text { 4. Increase the number of new offers for new } \\
\text { products }\end{array}$ & $\begin{array}{l}\text { Overcoming threats (minimize the } \\
\text { consequences of threats) } \\
\text { 1. Increase in customer service due to low } \\
\text { prices for services } \\
\text { 2. Retention of competitive positions due to } \\
\text { customer satisfaction. } \\
\text { 3. Professional staff will bring potential } \\
\text { customers } \\
4 \text { Image acquisition through quality services } \\
5 \text { Establishment of new business relations with } \\
\text { the administration, state. familiar inspections } \\
6 \text {. Fulfillment of scheduled inspections of the } \\
\text { main type of production } \\
\text { 7. Search for alternative suppliers of materials } \\
\text { and basic raw materials, to maintain a price } \\
\text { balance }\end{array}$ \\
\hline $\begin{array}{l}\text { Weaknesses: } \\
\text { 1. Lack of feedback } \\
\text { 2. Little information about a new }\end{array}$ & $\begin{array}{l}\text { Elimination of weaknesses } \\
\text { Provide affordable prices for services } \\
\text { Carrying out PR-actions: }\end{array}$ & $\begin{array}{l}\text { Non-standard events (maximum caution) } \\
\text { 1. Networking } \\
\text { 2. Attracting specialists from the production }\end{array}$ \\
\hline
\end{tabular}




\begin{tabular}{|c|c|c|}
\hline $\begin{array}{l}\text { product } \\
\text { 3. Lack of working capital; }\end{array}$ & $\begin{array}{l}\text { High level of professionalism } \\
\text { New Product Ads } \\
\text { Attracting investors }\end{array}$ & $\begin{array}{l}\text { implementation of the product } \\
\text { 3. Use of platforms to attract customers and } \\
\text { public relations of the company (technology } \\
\text { parks, etc.) } \\
\text { 4. Search and attraction of partners and } \\
\text { distributors }\end{array}$ \\
\hline $\begin{array}{l}\text { SWOT } \\
\text { Growth diversification strategy }\end{array}$ & $\begin{array}{l}\text { Opportunities: } \\
\text { 1. Decrease in economic risks } \\
\text { 2. Flexible reallocation of resources from } \\
\text { areas with low perspectives to where they } \\
\text { are high } \\
\text { 3. Investment Opportunity } \\
\text { 4. Expand existing markets and find new } \\
\text { ones. } \\
\text { 5. Improve the efficiency of using the } \\
\text { accumulated potential } \\
\text { 6. Ensure full capacity utilization } \\
\text { 7. Adapt to market conditions, actively } \\
\text { counteract rivals (including by buying up } \\
\text { their enterprises) } \\
\text { 8. Reduce partner dependency }\end{array}$ & $\begin{array}{l}\text { Threats: } \\
\text { 1. The complexity of the internal coordination } \\
\text { of units } \\
\text { 2. The uncertainty of the future is growing } \\
\text { 3. Reducing the role of the former core } \\
\text { production }\end{array}$ \\
\hline $\begin{array}{l}\text { Strengths: } \\
\text { 1. Survival is ensured by obtaining a } \\
\text { guaranteed level of profit. } \\
\text { 2. Achieving economic stability and } \\
\text { financial stability } \\
\text { 3. Gaining a dominant market position }\end{array}$ & $\begin{array}{l}\text { Development of competitive advantages } \\
\text { (maximize opportunities): } \\
\text { Continuous training of employees and the } \\
\text { use of this in competition } \\
\text { Need to follow the trend of technology } \\
\text { development } \\
\text { Continuous advertising and marketing }\end{array}$ & $\begin{array}{l}\text { Overcoming threats (minimize the } \\
\text { consequences of threats): } \\
\text { 1. The planned control of fixed assets, including } \\
\text { the main area of activity. } \\
\text { 2. The increase in customer service due to low } \\
\text { prices for services } \\
\text { 3. Retention of competitive positions due to } \\
\text { customer satisfaction. } \\
\text { 4. Professional staff will bring potential } \\
\text { customers } \\
\text { 5. Image acquisition through quality services }\end{array}$ \\
\hline $\begin{array}{l}\text { Weaknesses: } \\
\text { 1. requires new skills, new staff } \\
\text { 2. A relatively large budget is needed } \\
\text { 3. there may be uncertainty about the } \\
\text { managerial aspect of diversification } \\
\text { (for example, how the two teams of } \\
\text { leaders will collaborate with each } \\
\text { other) } \\
\text { 4. high-risk strategy for long-term } \\
\text { returns } \\
\text { 5. Significant cash reserves required } \\
\text { 6. There may be a tendency to transfer } \\
\text { shortcomings from an existing } \\
\text { enterprise to a new one. }\end{array}$ & $\begin{array}{l}\text { Elimination of weaknesses } \\
\text { 1. stay afloat in case of deterioration of } \\
\text { economic indicators by type of activity, } \\
\text { since possible failures in one area are offset } \\
\text { by success in others } \\
\text { 2. liquidate stocks of enterprises at their } \\
\text { peak on time and skillfully invest them in } \\
\text { growing promising firms } \\
\text { 3. economies of scale }\end{array}$ & $\begin{array}{l}\text { Non-standard events (maximum caution) } \\
\text { 1. Establishment of new business relations with } \\
\text { the administration, state. familiar inspections } \\
\text { 2. To expand through the acquisition of new } \\
\text { resources and technologies the possibility of } \\
\text { optimizing the range of products, financial } \\
\text { flows }\end{array}$ \\
\hline $\begin{array}{l}\text { SWOT } \\
\text { Cost reduction strategy }\end{array}$ & $\begin{array}{l}\text { Opportunities: } \\
\text { 1. Price reduction to attract customers and } \\
\text { create a customer base } \\
\text { 2. Increase in sales } \\
\text { 3. By reducing costs do not reduce the cost } \\
\text { of the product }\end{array}$ & $\begin{array}{l}\text { Threats: } \\
\text { 1. It is fraught with a protracted "price war" } \\
\text { 2. Decrease in profitability of the company } \\
\text { 3. Copying competitor cost reduction methods } \\
\text { 4. The risk of excessive concentration on cost } \\
\text { reduction - lack of marketing } \\
\text { 5. The decrease in consumer value of the goods }\end{array}$ \\
\hline $\begin{array}{l}\text { Strengths: } \\
\text { 1. Strong price competition } \\
\text { 2. Low brand change costs } \\
\text { 3. Cooperation with large customers } \\
\text { requiring a price reduction }\end{array}$ & $\begin{array}{l}\text { Development of competitive advantages } \\
\text { (maximize opportunities) } \\
\text { 1. Conducting targeted marketing for } \\
\text { customers with a more price-sensitive } \\
\text { customer } \\
\text { 2. Planned cost reduction through the search } \\
\text { for new suppliers and ways to reduce costs }\end{array}$ & $\begin{array}{l}\text { Overcoming threats (minimize the } \\
\text { consequences of threats) } \\
\text { 1. To lay the main production and alternative } \\
\text { 2. Determine the optimal level of the volume of } \\
\text { DOS. funds for primary and secondary } \\
\text { 3. Training } \\
\text { 4. Presentations to clients, lectures, information } \\
\text { refinement } \\
\text { 5. Integrity check of counterparties }\end{array}$ \\
\hline $\begin{array}{l}\text { Weaknesses: } \\
\text { 1. Standard or intended for a wide } \\
\text { range of consumer's goods } \\
\text { 2. The inability to diversify the goods } \\
\text { 3. Standard use of goods } \\
\text { 4. Competitors can copy cost reduction } \\
\text { methods }\end{array}$ & $\begin{array}{l}\text { Elimination of weaknesses } \\
\text { 1. Setting a clear cost plan and reducing } \\
\text { variable costs } \\
\text { 2. Reducing the cost of delivery of products } \\
\text { 3. Identification of new product markets } \\
\end{array}$ & $\begin{array}{l}\text { Non-standard events (maximum caution) } \\
\text { 1. Maintenance of planned inspections for cost } \\
\text { control } \\
\text { 2. Company privacy mode }\end{array}$ \\
\hline
\end{tabular}




\begin{tabular}{|c|c|c|}
\hline $\begin{array}{l}\text { SWOT } \\
\text { Integration Growth Strategy }\end{array}$ & $\begin{array}{l}\text { Opportunities: } \\
\text { 1. New specialists bring new customers } \\
\text { 2. The acquisition of new technologies } \\
\text { 3. New consumption markets } \\
\text { 4. Expansion of the product range } \\
\text { 5. Attracting new counterparties } \\
\text { 6. Improving the image of the company }\end{array}$ & $\begin{array}{l}\text { Threats: } \\
\text { 1. The risk of unprofitability } \\
\text { 2. Simple } \\
\text { 3. Low qualification } \\
\text { 4. High competition } \\
\text { 5. The risk of not selling the entire volume } \\
\text { 6. Disruptions in supply - lack of raw materials } \\
\text { (domestic) } \\
\text { 7. Low implementation efficiency } \\
\text { 8. Low customer information }\end{array}$ \\
\hline $\begin{array}{l}\text { Strengths: } \\
\text { 1. Accelerated Growth } \\
\text { 2. Scale up market coverage } \\
\text { 3. The acquisition of contracts for the } \\
\text { full cycle of work } \\
\text { 4. The increase in stages for one artist }\end{array}$ & $\begin{array}{l}\text { Development of competitive advantages } \\
\text { (maximize opportunities) } \\
\text { 1. Improving old products and developing a } \\
\text { new product } \\
\text { 2. Cost optimization } \\
\text { 3. Diversification of the stages }\end{array}$ & $\begin{array}{l}\text { Overcoming threats (minimize the } \\
\text { consequences of threats) } \\
\text { 1. To lay the main production and alternative } \\
\text { 2. Determine the optimal level of the volume of } \\
\text { DOS. funds for primary and secondary } \\
\text { 3. Training } \\
\text { 4. Presentations to clients, lectures, information } \\
\text { refinement } \\
\text { 5. Integrity check of counterparties } \\
\end{array}$ \\
\hline $\begin{array}{l}\text { Weaknesses: } \\
\text { 1. Poor awareness } \\
\text { 2. Low technological equipment } \\
\text { 3. Lack of competencies } \\
\text { 4. Lack of admin control. The staff } \\
\text { 5. The cost of continuing education } \\
\text { 6. Lack of relevant standards and } \\
\text { regulations } \\
\text { 7. Weak customer awareness }\end{array}$ & $\begin{array}{l}\text { Elimination of weaknesses } \\
\text { 1. Marketing research } \\
\text { 2. Direct marketing } \\
\text { 3. Scheduled continuing education seminars } \\
\text { 4. Compilation of personnel reserve } \\
\text { 5. Budgeting for staff training } \\
\text { 6. Review of accounting policies }\end{array}$ & $\begin{array}{l}\text { Non-standard events (maximum caution) } \\
\text { 1. Maintenance of planning meetings } \\
\text { 2. Absorption of small innovative enterprises } \\
\text { with the presence of } \\
\text { - administrative staff } \\
\text { - customer base }\end{array}$ \\
\hline
\end{tabular}

It is worth noting that the standard procedure for reaching a solution in any business, given the choice of strategy, combines the following stages:

- identification of the problem/possible risks;

- information collection;

- selecting the analysis method;

- $\quad$ select a group of experts for each issue.;

- creating a request to experts;

- collecting expert responses;

- developing a computer model (cognitive, hierarchical, etc.);

- formulation of decisions and conclusions on the existing issue / problem;

- development of new goals and objectives in accordance with the established solutions. [10].

In addition, a novice entrepreneur must necessarily resort to the techniques and tools of marketing research. So, for example, at the startup stage, conduct a general assessment of the market for your product:

- market assessment using Potential Available Market $(\mathrm{PAM})^{1}$, Total Addressable Market (TAM) ${ }^{2}$, Served/Serviceable Available Market (SAM $)^{3}$, Serviceable \& Obtainable Market (SOM)

- demand assessment - determine the approximate level of demand for a given product;

- sales forecasting - determine the expected level of sales for a given demand.

When a company moves from one stage to another, it becomes necessary to use new or additional techniques, for example, when moving to the early growth stage, the company can use the methods of Primary Marketing - the first, on a small scale, launch of a product, used to determine the possible adoption of the product when launching for more wide market or conduct elasticity - to understand how sensitive the consumer is to price changes. This also includes methods for creating a sales plan, which will include a customer base, a sales funnel, a plan for communicating information to potential customers of the company, through direct marketing or digital marketing, as well as other methods. All this influences quite strongly the decision-making regarding the product and strategic development of the company, as well as the pricing of the product and the financial and economic plan of the company.

It is very important for novice entrepreneurs who are involved in the development and commercialization of their innovative technologies, in the case of cascading strategies, to understand their product plan, which should include at least the terms of development and the timing of products on the market. As one of such schemes, one can cite as an example a table of one of the possible plans for applying strategies in a cascading way for years, where the plan is formed from the beginning of the product development and testing (R\&D) stage to entering the market with one strategy, and then switches to a new one, developing and introducing new products. This diagram is presented as a demonstration and can be changed in various conditions and specifics of the enterprise (Fig.1).

\footnotetext{
1 potential market size

2 target market volume

${ }^{3}$ available market volume

${ }^{4}$ really achievable market volume
} 
Grocery Business Plan

Small Innovative Enterprise cascading methods

Sales of company products on a

time line by year

- Product development

- Commercialization

- Expansion (market growth)

- Cost reduction

Company strategies on the time line by year

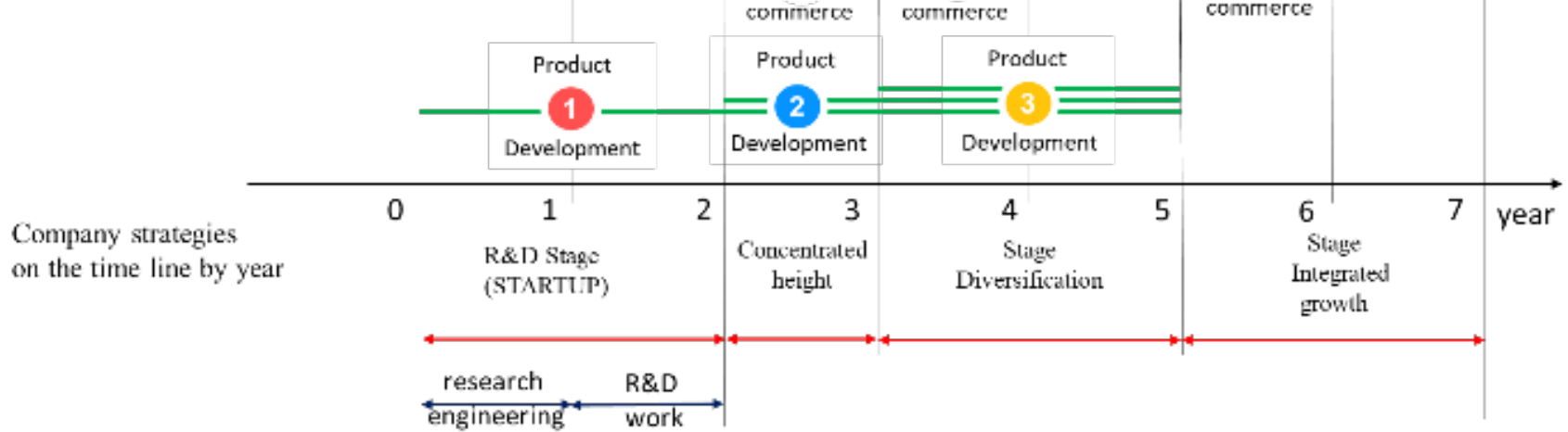

Fig. 1. Variant of the Business Plan of a small innovative enterprise in a cascading manner by year (Source: Compiled by the authors)

It should be noted that for companies that work in innovative activities and not only in this area, the period of development or life cycle (Fig. 2) can be divided into the following stages:

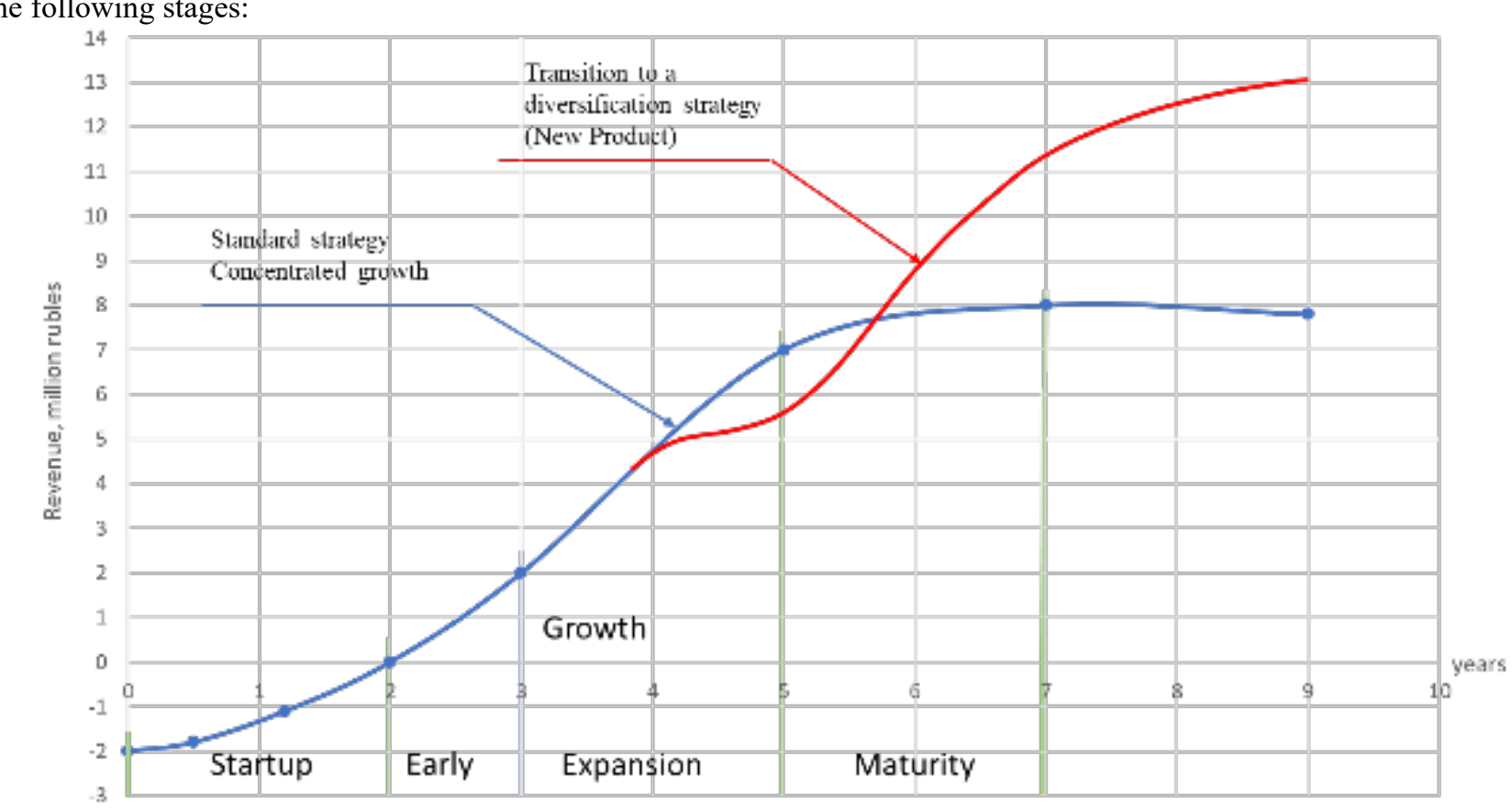

Company Stages

Fig. 2. The stages of enterprise growth, taking into account the change of strategies over 10 years and the change in the company's revenue (Source: Compiled by the authors - based on worldbank.org, 2019)

As a rule, it is additionally worthwhile to attribute the stage of a company to IPO after the maturity stage, but this applies more to large innovative enterprises, and in this case we consider small innovative enterprises and small business companies. Such a cycle can be presented
- $\quad$ startup;

- $\quad$ stage of growth (early / expansion)

- maturity. 
analyze and predict the work of your company, for example:

1) At the Startup stage - Conduct a SWOT analysis applying it both to the choice of a company's strategy and to evaluate the product of its advantages and disadvantages compared to competitors. Use marketing tools that were previously considered, for example, PAM, TAM, SAM, SOM to assess the market. To formulate a product plan for the terms of product release according to the cascading method of business strategy.

2) At the growth stage, a repeated SWOT analysis is necessary, the use of deeper marketing research and the formation of a sales plan, the adjustment of the product plan by the timing.
3) At the maturity stage, it is necessary to use the same tools, it is also necessary to develop and introduce additional regulations for the conduct of certain operations of a commercial, technological or financial nature, for the stability of the enterprise's commercial activities and the possibility of developing new models and business development plans.

\section{Results}

As a result, threats that appear in a specific period of time for one strategy can be compensated by the capabilities of another, thereby saving the entrepreneur from a crisis situation in the company as a whole (Fig. 3).

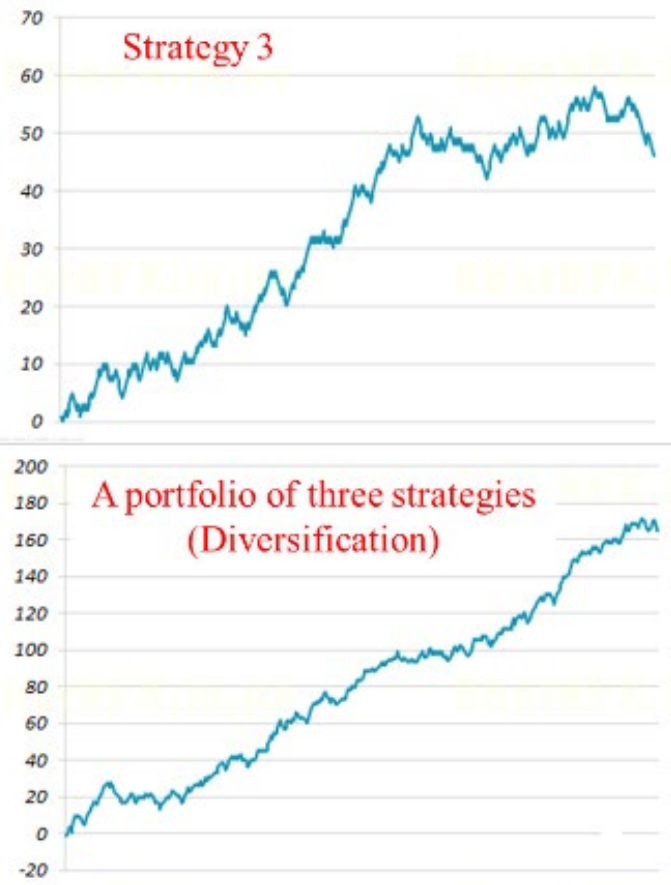

Fig. 3. The result of the economic activity of the company when combining several strategies (Source: [7])

\section{Conclusion}

By defining new paths and new approaches, working ahead of the curve, it will open up new opportunities for Russia and will make it possible to occupy certain and possibly completely new niches in the world market of high-tech products and diversify its export base. Thus, a more open Russian market, bringing Russian legislation to the international level, as well as closer interaction with the global economic system can positively affect the business climate in Russia and significantly contribute to the competitiveness and growth of investment attractiveness of the service sector. and technology. In addition, it is worth considering the application of such measures that the expert community focuses on:

- tighten control over the implementation of decisions and programs;

- improve legislation;

- introduce tax incentives for innovative activity of enterprises
At the same time, novice entrepreneurs and developers in the field of innovation are also recommended:

- take into account and apply the strategy for small innovative enterprises according to the SWOT analysis for monitoring and forecasting upcoming events (production or economic);

- $\quad$ use the tools of marketing research, SWOT analysis and the formation of a product plan for the life of the company;

- based on SWOT analysis, build a cognitive model that evaluates the management process and its various scenarios in dynamics, and to optimize decision-making, set the inverse problem using a genetic algorithm; [10]

- $\quad$ keep in mind that the forecast should be based on SWOT analyzes as a starting point, and in the future, it is necessary to apply regulations to develop new models and plans for business development. 


\section{Acknowledgments}

The study was carried out within the framework of RFBR grants 19-07-00455 and 20-04-60185.

\section{Reference}

[1] Kuznetsova G.V. The current situation of Russia in the global market of innovative technologies // Russian Economic Bulletin. 2017. No. 2.

[2] Tsypin I.S., Tsypin S.I. Strategy for the development of the Russian economy until 2013 // Modern aspects of the development of the Russian economy: problems and prospects. All-Russian Scientific and Practical Conference. April 2013. M.: Publishing House of MGIU. S. 21.

[3] Chubais A. Industry breakthroughs // BRICS. Business magazine. 2014.

[4] Revich Yu.V. Malinovsky B.N. Information technology in the USSR: creators of Soviet computing. St. Petersburg: BHV-Petersburg, 2014. S. 8.9.

[5] Paul Harmon. Business Process Change: A Business Process Management Guide for Managers and Process Professionals // Published by Elsevier Inc. 2019.

[6] Paul Haig. Management concepts and business models. // Alpina Publisher, 2019.S. 376

[7] Goldstein G.Ya. Strategic management: Lecture notes. Taganrog: TSURE, 2003. $95 \mathrm{p}$.

[8] Malashkina O.F. Consortium as a model for managing the development of high-tech companies // Economy and society: modern models of development. - 2020. - Volume 10. - no. 1.

[9] Sadovaya A.M., Ignatievsky V. A. Strategic analysis of the company //Polythematic network electronic scientific// №2(36), 2020.

[10] Raikov A.N., Panfilov S.A. Convergent Decision Support System with Genetic Algorithms and Cognitive Simulation $/ / 7^{\text {th }}$ IFAC Conference on Manufacturing Modelling, Management, and Control, MIM 2013 Saint Petersburg, June 19-21, 2013.1108-1113 p.

\section{About the authors}

Denis S. Seleznev, postgraduate, National Research University of Oil and Gas n.a. I.M. Gubkin, Moscow, Russia. E-mail: skyforward11@gmail.com

Ozdoeva Alina Kh., $\mathrm{PhD}$ in economics., scientific researcher, National Research University of Oil and Gas n.a. I.M. Gubkin, Moscow, Russia. E-mail: $\underline{4305 @ b k . r u}$ 